\title{
ТЕРАПИЈА СО ПРИМЕНА НА ЖИВОТНИ КАЈ ДЕЦА СО ПРЕЧКИ ВО РАЗВОЈОТ
}

\section{Кратка содржина}

Иако терминот терапија со примена на животни е релативно нов, употребата на животните за надминуване на болест или настаната состојба кај луѓето не е нова идеја. Најрана примена на животните во тераписки цееи била забележана во Белгија, каде животните и луѓето биле рехабилитирани заедно, а животните претставувале значаен дел од природната терапија на луѓето.

Примената на различни терапии и активности со децьата со попреченост со иел подобруванье на нивната цеелокупна состојба и реализираньето на секојдневните активности се проширува. Еден од современите пристапи во третманот на децзата со попреченост е терапијата со примена на куче и се фокусира на подобруване на физичкото, когнитивното и социиемоционалното функциониране на личноста.

Нашето истражуване беше организирано во облик на квазиексперимент, во контролната и експерименталната група беа вклучени деца со моторни нарущуваньа, проблеми во говорот и децза со проблеми во однесуването. Контролната група подложеше на класичен третмин со специјален едукатор и рехабилитатор, додека во експерименталната група беше применета терапија со куче.

Истражуваната покажуваат дека присуството на куче за време на терапиите им помага на децата да го подобрат своето расположение, ја зголемуваат волјата за активно учество, полесно емоционално изразуванье, ги подобруваат или надминуваат говорните нарушувана, се поттикнува комуникацијата, се подобрува психомоторниот развој и се постигнуваат низа физиолошки придобивки.

клучни зборови: ТЕРАПИЈА, ЖИВОТНИ, КУЧЕ, ПОПРЕЧЕНОСТ, РАЗВОЈНИ ПРИДОБИВКИ

\section{Вовед}

Историски гледано првите записи за придонесот на животните во добросостојбата на луѓето датира уште од 1600-тите години, кога Џон Док во своите дискусии пишува за примена на мали животни со цел развој на емпатија и одговорност кај децата (Fine, 2000). Вдомувањето и припитомувањето на животните започнува уште пред повеќе од 2 мидиони години, а уште во Античка Грција биле забележани емоционалните и физичките придобивки од контактот со животните. Во 1792 година во Ангдија било забележано применување на животните од фарма во третман на ментално 
болни пациенти, во насока на намалување на изолацијата и ограничувањата (Baun \& McCabe, 2000). Подоцна во Германија во институции за ментално болни и за бездомници биле користени животни за тераписки цели, а во 1942 година во Америка се користеле животни за олеснување на третманот и лекувањето на воените инвалиди. Психологот Boris Levinson во 1960 година ја концептуадизира врската помеѓу луѓето и животните и го креира терминот терапија со животни, користејќи го своето куче во работа со интровертно интелектуално попречено дете и притоа забележувајќи значителни позитивни промени (Levinson, Mallon, 1997).

Кучето е првото животно кое човекот го припитомил и чувал во домашни услови. Во гробница во Израел која датира од пред 14.000 години, најдени се остатоци од човек како лежи со едната рака поставена на градите на мало куче, а припитомувањето започнува пред 12.000 години, исто така во Израел. Се верува дека историјата на хуманата еволуција е директно поврзана со еволуцијата на кучињата, притоа верувајќи дека предизвикало функционални промени во човековиот мозок. Во средниот век во Белгија била нотирана терапевтска примена на кучиња во третман на лица со пречки во развојот. Од средината на 1970-тите години кога терапијата со примена на кучиња беше воведена во клинички услови, овој третман се нуди во терапевтски центри, програми за лица со посебни потреби, болници, старечки домови, затвори и установи за ментално здравје, при тоа без никакви возрасни ограничувања. Третманот е ефикасен за деца, адолесценти, возрасни и стари луѓе (Alliance of therapy dogs, 2018).

\section{Видови на интервенции со примена на животни}

Интервенцијата со примена на животни е секоја интервенција која намерно вклучува животни како дел од терапевтскиот процес. Вакви интервенции вообичаено се применуваат со пациенти со физички проблеми, интелектуални, психички, невролошки и моторни растројства, но може да се применуваат и кај луѓе со депресија, анксиозност, посттрауматски стрес инт. Пред примената потребно е да се направат прегледи и евалуации со цел да се детерминираат можните контраиндикации. Имплементацијата на интервенцијата може да бара вклучување на мултидисциплинарен тим со раздични задачи и одговорности, во зависност од интервенцијата. Самата интервенција со примена на животни е поделена во три категории (AVMA, 2019):

1. Терапија со примена на животни - интервенција која се применува како поддршка на други терапии (котерапија) и се фокусира на третман на физички проблеми, интелектуални, психички, когнитивни, емоционални, релациски, невролошки и моторни нарушувања.

2. Едукација со примена на животни - едукациска и/или рехабилитациска интервенција наменета за здрави, но и дица со пречки во 
развојот, кои имаат растројства во однесувањето. Интервенцијата има за цел подобрување на психофизичката и социјалната добросостојба и квалитет на живот на дицата, зголемување на нивното самовреднување. Реедукација на однесувањето се постигнува со посредство на животните. Оваа интервенција обично се применува кај продолжена хоспитализација или повторни сместувања во рехабилитациски центри, релациски тешкотии (attachment проблеми) во детство или адолесценција, емоционални растројства, тешкотии и проблеми во однесувањето и социокултурна адаптација.

3. Активност со примена на животни - епизодна, рекреативна интервенција наменета за здрави лица и лица со инвалидност, со цел подобрување на нивниот квалитет на живот. Во активностите врската со животните претставува извор на знаење и сензорно-емоционална стимулација. Во некои случаи активностите со животни се воведен чекор во едукацијата и терапијата и има за цел развој на вештини преку грижа за животните, зголемување на одговорноста и стимулација на моторна активност.

Генерално сите три категории на интервенции се изведуваат со помош на мултидисциплинарен тим, каде секој член е обучен за интервенции со примена на животни. Животното кое се користи за интервенција претходно е подложено на детален ветеринарен преглед и неговото поведение се следи во текот на целокупната интервенција. Сите животни кои се вклучуваат посебно оние кои се издожени на директен контакт и активности мора да бидат тренирани и едуцирани на специфичен начин, со цел да се стекнат со неопходните компетенции.

Најзастапена е интервенцијата со примена на кучиња, животно кое е најчесто присутно во животот на луѓето. Притоа, интервенцијата не е само шетање со кучето или игра, таа претставува планирана програма каде индивидуата се вклучува со животното во фокусиран, претходно прецизиран и детално поставен програм (Kruger \& Serpell, 2006). Кај кучињата конкретно, постојат три основни видови на интервенции:

1. Кучиња за терапевтска посета: станува збор за домашни миленичиња кои сопствениците повремено ги носат на посета кај пациенти кои се долго време хоспитадизирани во болница, старечки домови, рехабилитациски институции. Кучињата им помагаат во подобрување на психофизичката состојба. Според направени истражувања контактот со кучињата предизвикува создавање окситоцин (хормон на врска), допамин (хормон на среќа) и намалување на количеството на кортизол (хормон на стрес).

2. Кучиња кои се користат како медијатори во третман и рехабилитација: им помагаат на физиотерапевтите, окупационите терапевти, специјални едукатори и рехабилитатори, догопедите во реализација на целите на третманот и закрепнување на пациентот. 
Овозможуваат подобрување на грубата и фина моторика, визиомоторната координација, рамнотежа, говор, интеракција.

Понов вид на интервенција претставува техниката „Читање на кучиња“. Програмата е креирана со цел на сѐ поголемиот број на деца со тешкотии во читањето и јазичното изразување да им помогне да ги изградат и развијат вербалните способности и вокабуларот, да ја подобрат способноста за разбирање на прочитаното, да развијат самодоверба. Кучињата се пасивни слушатели кои не критикуваат и не сугерираат, имаат доволно време да сослушаат без осуда и делуваат мотивациски, стимулативно, смирувачки (Pillow-Price et all., 2014).

3. Кучиња за помош: овие кучиња обично работат во старечки или згрижувачки домови и се добро тренирани да им помагаат на корисниците да ги реализираат секојдневните обврски без да зависат од друго дице. Во последните години се сретнуваат повеќе раздични видови на кучиња за помош кои се користат во раздични приАики:

- Куче водич за слепи лица;

- Куче алармер за глуви лица;

- Водич на количка за телесно инвалидно лице;

- Алармер за дијабетес;

- Кучиња за алармирање на епилептичен напад;

- Кучиња кои помагаат при епилептични напади;

- Психијатриски кучиња;

- Кучиња за поддршка на лица со аутистичен спектар на нарушување;

- Кучиња за откривање алергени.

Без раздика кој облик на интервенција ќе се применува, кучињата кои се користат секогаш треба да бидат добро истренирани и подготвени за раздични ситуации и контакти со луѓе. Кучињата може да бидат од различна раса и со раздичен карактер, но сите мора да поседуваат одредени карактеристики неопходни за успешна реализација на интервенцијата: да бидат мирни, стабилни (не избувливи), да не се агресивни, да се способни да ги инхибираат своите импулси, да се снаоѓаат во непредвиддиви ситуации (дизгав под, јаки миризби, силни звуци итн.) толерантни кон гушкање и непознати луѓе, да имаат желба за игра и соработка. Пред тренингот и обуката кучињата се подложни на евалуација, покрај физичкиот преглед, возраста, се проценува нивниот карактер и односот со старателот. Обуката на кучињата трае од 6 недели за терапевтска посета и читање до 18 месеци за раздични сервисни услуги (Clonowski, 2015). 


\section{Метододогија на истражување}

Целта на истражувањето беше да се детерминира влијанието од присуството на животното - кучето, за време на третманот на децата со пречки во развојот, односно да се увиди дали примената на кучиња во терапијата на деца со раздични видови на попреченост ќе даде подобри резултати за пократок временски интервал од класичниот третман. Досега, кај нас, во Република Северна Македонија не се спроведувала терапија со кучиња кај децата со попреченост, што значи дека во овој дел сме пионери. Истражувањето се реализираше преку квазиексперимент во временска рамка од три месеци, со контролна и експериментална група, секоја составена од по три ученика со пречки во развојот, претходно проценети, евалуирани и сразмерно распределни во групите. Експерименталната група беше подложена на терапија со примена на куче, додека пак контролната со класичен дефектолошки третман. Пред почетокот на третманот беше направено контролно проценување на моторните, говорно-јазичните способности и начинот на однесување при секојдневните активности на децата и врз основа на резултатите беа подготвени тераписки програми, т.е. планови за работа со точно определени цели, методски постапки и ресурси. Истите проценки се спроведоа и на половина од третманот (после 1,5 месец) и на крај на третманот. За собирање на податоците беа користени чек-дисти за квазиексперимент и транскрибирање на податоците од видеозаписите и сликите, кои ги реализиравме преку програмата АТLAS.ti (програма за квалитативна анализа на текстуални, графички, аудио и видеоподатоци). Прво, ги компариравме ефектите од вежбите со и без примена на куче, и после реализиравме компарација со други слични истражувања. Промените во резултатите ги споредувавме со помош на техниката Difference-in-differences (DID) (Раздика во раздиките), додека пак проценките беа вршени со помош на Скала за проценка на адаптивно однесување (Adaptive Behavior Assessment System- ABAS) (Harrison \& Oakland, 2000-2003). Бодовите од скалата се претставени со специфичен опсег во квантитативна скала како на пример: екстремно ниско, гранично, потпросечно, просечно, натпросечно, супериорно, многу супериорно.

Истражувањето се реализираше во Пет центарот „АвАв Хепи Дог“ во Скопје, примерокот се состоеше од 6 деца со посебни потреби, на возраст помеѓу 7 и 9 години, по два испитаника од секоја категорија (моторни нарушувања, растројства во говорот и комуникацијата и тешкотии во реапизирање на секојдневните активности).

\section{Анализа на резултати со дискусија}

Иницијалните мерења кај испитаниците, детерминираа резултати во склад со видот и степенот на попреченоста, кај децата со моторни нарушува најслаб резултат беше постигнат во областа на моториката - екстремно низок, комуникацијата исто така беше засегната како резултат на 
спазам на мускулите на говорниот апарат, додека социјадизацијата е добро скорувана. Кај испитаниците со нарушувања во говорот, најслаб резултат е постигнат во областа на комуникацијата - под просек, моториката и социјализацијата се на гранична динија, додека кај испитаниците со проблеми во однесувањето, моториката е развиена во склад со возраста, но комуникацијата и социјализацијата се под бараниот просек.

Табела 1. Резултати од првата проценка кај испитаниците

\begin{tabular}{|c|c|c|c|c|c|c|}
\hline $\begin{array}{l}\text { Испи- } \\
\text { таник }\end{array}$ & Домен & $\begin{array}{l}\text { Зби- } \\
\text { рен } \\
\text { ре- } \\
\text { зудт. } \\
\text { (sum } \\
\text { score) }\end{array}$ & $\begin{array}{l}\text { Процен- } \\
\text { тен } \\
\text { резултат } \\
\text { (percentile } \\
\text { score) }\end{array}$ & $\begin{array}{l}\text { Резулт. } \\
\text { за } \\
\text { генерал- } \\
\text { ниот } \\
\text { адапти- } \\
\text { вен ком- } \\
\text { позит } \\
\text { (ГАК) } \\
\text { (GAC) }\end{array}$ & $\begin{array}{l}\text { Интер- } \\
\text { вал на } \\
\text { раздика- } \\
\text { та Con- } \\
\text { fidence } \\
\text { interval }\end{array}$ & $\begin{array}{l}\text { Квалита- } \\
\text { тивен } \\
\text { опсег } \\
\text { Qualita- } \\
\text { tive range }\end{array}$ \\
\hline \multirow{3}{*}{$\begin{array}{l}\text { А. } \mathrm{E}^{*} \\
\text { моторни на- } \\
\text { рушувања }\end{array}$} & $\begin{array}{c}\text { Мото- } \\
\text { рика }\end{array}$ & 14 & 0,5 & 61 & $<70$ & $\begin{array}{c}\text { Екстрем. } \\
\text { ниско }\end{array}$ \\
\hline & $\begin{array}{c}\text { Комуни- } \\
\text { кација }\end{array}$ & 20 & 21 & 88 & $80-89$ & $\begin{array}{c}\text { Под про- } \\
\text { сек }\end{array}$ \\
\hline & $\begin{array}{l}\text { Соција- } \\
\text { лизација }\end{array}$ & 29 & $>90$ & 120 & $120-129$ & $\begin{array}{c}\text { Суперио- } \\
\text { рен }\end{array}$ \\
\hline \multirow{3}{*}{$\begin{array}{l}\text { Е. } C^{* *} \\
\text { моторни на- } \\
\text { рушувања }\end{array}$} & $\begin{array}{c}\text { Мото- } \\
\text { рика }\end{array}$ & 17 & 2 & 69 & $<70$ & $\begin{array}{c}\text { Екстрем. } \\
\text { ниско }\end{array}$ \\
\hline & $\begin{array}{c}\text { Комуни- } \\
\text { кација }\end{array}$ & 14 & 5 & 75 & $71-79$ & $\begin{array}{c}\text { Гранична } \\
\text { Аинија }\end{array}$ \\
\hline & $\begin{array}{l}\text { Соција- } \\
\text { дизација }\end{array}$ & 46 & $>90$ & 120 & $120-129$ & $\begin{array}{c}\text { Суперио- } \\
\text { рен }\end{array}$ \\
\hline \multirow{3}{*}{$\begin{array}{l}\text { А.Ш } \\
\text { оштетен } \\
\text { слух }\end{array}$} & $\begin{array}{l}\text { Мото- } \\
\text { рика }\end{array}$ & 63 & $>90$ & $111-131$ & $71-79$ & $\begin{array}{c}\text { Гранична } \\
\text { линија }\end{array}$ \\
\hline & $\begin{array}{c}\text { Комуни- } \\
\text { кација }\end{array}$ & 16 & 10 & 56 & $80-89$ & $\begin{array}{c}\text { Под про- } \\
\text { сек }\end{array}$ \\
\hline & $\begin{array}{l}\text { Соција- } \\
\text { лизација }\end{array}$ & 22 & 53 & 91 & $90-109$ & $\begin{array}{c}\text { Нормал. } \\
\text { линија }\end{array}$ \\
\hline \multirow{2}{*}{$\begin{array}{l}\text { E.M**** } \\
\text { оштетен } \\
\text { слух }\end{array}$} & $\begin{array}{l}\text { Мото- } \\
\text { рика }\end{array}$ & 62 & $>90$ & $119-131$ & $120-129$ & $\begin{array}{c}\text { Гранична } \\
\text { линија }\end{array}$ \\
\hline & $\begin{array}{c}\text { Комуни- } \\
\text { кација }\end{array}$ & 6 & 0,2 & 25 & $\leq 70$ & $\begin{array}{c}\text { Екстрем. } \\
\text { ниско }\end{array}$ \\
\hline
\end{tabular}




\begin{tabular}{|c|c|c|c|c|c|c|}
\hline & $\begin{array}{l}\text { Соција- } \\
\text { лизација }\end{array}$ & 20 & 47,3 & $83-89$ & $80-89$ & $\begin{array}{c}\text { Под про- } \\
\text { сек }\end{array}$ \\
\hline \multirow{3}{*}{$\begin{array}{l}\text { Ш.Б**** } \\
\text { * } \\
\text { проблеми во } \\
\text { однесување }\end{array}$} & $\begin{array}{l}\text { Мото- } \\
\text { рика }\end{array}$ & 51 & $>90$ & $111-131$ & $110-119$ & $\begin{array}{c}\text { Над про- } \\
\text { сек }\end{array}$ \\
\hline & $\begin{array}{c}\text { Комуни- } \\
\text { кација }\end{array}$ & 13 & 3 & 47 & $\leq 70$ & $\begin{array}{c}\text { Екстрем. } \\
\text { ниско }\end{array}$ \\
\hline & $\begin{array}{c}\text { Соција- } \\
\text { дизација }\end{array}$ & 12 & 10 & 56 & $\leq 70$ & $\begin{array}{c}\text { Екстрем. } \\
\text { ниско }\end{array}$ \\
\hline \multirow{3}{*}{$\begin{array}{l}\text { Д.М } \mathbf{M}^{* * * *} \\
\text { проблеми во } \\
\text { однесување }\end{array}$} & $\begin{array}{l}\text { Мото- } \\
\text { рика }\end{array}$ & 47 & 82 & 105 & $90-109$ & $\begin{array}{c}\text { Над про- } \\
\text { сек }\end{array}$ \\
\hline & $\begin{array}{c}\text { Комуни- } \\
\text { кација }\end{array}$ & 7 & 0,5 & 30 & $\leq 70$ & $\begin{array}{c}\text { Екстрем. } \\
\text { ниско }\end{array}$ \\
\hline & $\begin{array}{l}\text { Соција- } \\
\text { дизација }\end{array}$ & 5 & 1 & 33 & $\leq 70$ & $\begin{array}{c}\text { Екстрем. } \\
\text { ниско }\end{array}$ \\
\hline
\end{tabular}

Табела 2. Резултати од крајната проценка кај испитаниците

\begin{tabular}{|c|c|c|c|c|c|c|}
\hline $\begin{array}{l}\text { Испи- } \\
\text { таник }\end{array}$ & Домен & $\begin{array}{l}\text { Збирен } \\
\text { резулта- } \\
\text { T } \\
\text { (sum } \\
\text { score) }\end{array}$ & $\begin{array}{l}\text { Процен- } \\
\text { тен ре- } \\
\text { зултат } \\
\text { (percen- } \\
\text { tile } \\
\text { score) }\end{array}$ & $\begin{array}{l}\text { Резулт. } \\
\text { за гене- } \\
\text { радниот } \\
\text { адапти- } \\
\text { вен ком- } \\
\text { позит } \\
\text { (ГАК) } \\
\text { (GAC) }\end{array}$ & $\begin{array}{l}\text { Интер- } \\
\text { вад на } \\
\text { раздика- } \\
\text { та Con- } \\
\text { fidence } \\
\text { interval }\end{array}$ & $\begin{array}{l}\text { Квадита- } \\
\text { тивен } \\
\text { опсег } \\
\text { Qualita- } \\
\text { tive range }\end{array}$ \\
\hline \multirow{3}{*}{$\begin{array}{l}\text { A. } \mathrm{E}^{*} \\
\text { моторни на- } \\
\text { рушувања }\end{array}$} & $\begin{array}{l}\text { Мото- } \\
\text { рика }\end{array}$ & 45 & 75 & 110 & $110-119$ & $\begin{array}{l}\text { Над про- } \\
\text { сечно }\end{array}$ \\
\hline & $\begin{array}{l}\text { Комуни- } \\
\text { кација }\end{array}$ & 29 & 50 & 100 & $90-109$ & $\begin{array}{l}\text { Средна } \\
\text { вредност }\end{array}$ \\
\hline & $\begin{array}{l}\text { Соција- } \\
\text { лизација }\end{array}$ & 48 & $>90$ & 120 & $120-129$ & $\begin{array}{l}\text { Суперио- } \\
\text { рен }\end{array}$ \\
\hline \multirow[t]{3}{*}{$\begin{array}{l}\text { E.C } \\
\text { моторни на- } \\
\text { рушувања }\end{array}$} & $\begin{array}{l}\text { Мото- } \\
\text { рика }\end{array}$ & 23 & 9 & 80 & $80-89$ & $\begin{array}{l}\text { Под сре- } \\
\text { ден про- } \\
\text { сек }\end{array}$ \\
\hline & $\begin{array}{l}\text { Комуни- } \\
\text { кација }\end{array}$ & 25 & 32 & 92 & $90-109$ & $\begin{array}{l}\text { Средна } \\
\text { вредност }\end{array}$ \\
\hline & $\begin{array}{l}\text { Соција- } \\
\text { дизација }\end{array}$ & 29 & $>90$ & 120 & $120-129$ & $\begin{array}{l}\text { Суперио- } \\
\text { рен }\end{array}$ \\
\hline
\end{tabular}




\begin{tabular}{|c|c|c|c|c|c|c|}
\hline \multirow{3}{*}{$\begin{array}{l}\text { А.Ш*** } \\
\text { оштетен } \\
\text { слух }\end{array}$} & $\begin{array}{l}\text { Мото- } \\
\text { рика }\end{array}$ & 63 & $\geq 90$ & $111-131$ & $71-79$ & $\begin{array}{l}\text { Гранична } \\
\text { динија }\end{array}$ \\
\hline & $\begin{array}{l}\text { Комуни- } \\
\text { кација }\end{array}$ & 25 & 32 & 80 & $80-89$ & $\begin{array}{l}\text { Над про- } \\
\text { сек }\end{array}$ \\
\hline & $\begin{array}{l}\text { Соција- } \\
\text { дизација }\end{array}$ & 25 & 86 & 107 & $90-109$ & Просечен \\
\hline \multirow{3}{*}{$\begin{array}{l}\text { E.M**** } \\
\text { оштетен } \\
\text { слух }\end{array}$} & $\begin{array}{l}\text { Мото- } \\
\text { рика }\end{array}$ & 62 & $\geq 97$ & $119-131$ & $120-129$ & $\begin{array}{l}\text { Суперио- } \\
\text { рен }\end{array}$ \\
\hline & $\begin{array}{l}\text { Комуни- } \\
\text { кација }\end{array}$ & 9 & 0.1 & 22 & $\leq 70$ & $\begin{array}{l}\text { Екстрем. } \\
\text { ниско }\end{array}$ \\
\hline & $\begin{array}{l}\text { Соција- } \\
\text { дизација }\end{array}$ & 25 & $\geq 90$ & $108-131$ & $90-109$ & Просечен \\
\hline \multirow{3}{*}{$\begin{array}{l}\text { Ш.Б } \\
\text { **** } \\
\text { проблеми во } \\
\text { однесување }\end{array}$} & $\begin{array}{l}\text { Мото- } \\
\text { рика }\end{array}$ & 55 & $\geq 90$ & $111-131$ & $110-119$ & $\begin{array}{l}\text { Над про- } \\
\text { сек }\end{array}$ \\
\hline & $\begin{array}{l}\text { Комуни- } \\
\text { кација }\end{array}$ & 14 & 5 & 50 & $\leq 70$ & $\begin{array}{l}\text { Екстрем. } \\
\text { ниско }\end{array}$ \\
\hline & $\begin{array}{l}\text { Соција- } \\
\text { лизација }\end{array}$ & 19 & 18 & $81-82$ & $80-89$ & $\begin{array}{l}\text { Под про- } \\
\text { сек }\end{array}$ \\
\hline \multirow{3}{*}{$\begin{array}{l}\text { Д.M } \mathbf{M}^{* * * *} \\
* * \\
\text { проблеми во } \\
\text { однесување }\end{array}$} & $\begin{array}{l}\text { Мото- } \\
\text { рика }\end{array}$ & 50 & $\geq 90$ & $108-131$ & $90-109$ & $\begin{array}{l}\text { Над про- } \\
\text { сек }\end{array}$ \\
\hline & $\begin{array}{l}\text { Комуни- } \\
\text { кација }\end{array}$ & 12 & 2 & $40-41$ & $\leq 70$ & $\begin{array}{l}\text { Екстрем. } \\
\text { ниско }\end{array}$ \\
\hline & $\begin{array}{l}\text { Соција- } \\
\text { дизација }\end{array}$ & 13 & 16 & $56-58$ & $\leq 70$ & $\begin{array}{l}\text { Екстрем. } \\
\text { ниско }\end{array}$ \\
\hline
\end{tabular}

Во првата група на испитаници со тешкотии во областа на моториката, констатиравме дека за раздика од класичните вежби, кои после последната проценка на способности пак ни дадоа резултати на моториката од екстремно ниско ниво, вкдучувањето на куче во процесот на рехабилитација не донесе големи и видливи промени во развојот на моториката, но покажа извесно подобрување во одделни сегменти на моторните способности, кои беа во гранична динија, а децата манифестираа упорност и се обидуваа да ги завршат задачите и активностите до крај. Можеме да констатираме дека терапијата со куче ги мотивира децата да учествуваат во 
терапијата, ја зголемува нивната волја и желба за да работат, а подобрувањето на моторните перформанси бара долготрајна и посветена работа за да има мерливи резултати. Нашите наоди се преклопуваат со резултатите на истражувањето на Tepfer и сор. во 2017 година, според кои терапијата со куче игра важна улога во моторните вештини, физичката активност и квалитетот на живот. Авторите дошле до заклучок дека семејното куче може да игра улога во здравиот начин на живот кај децата со церебрална парализа. Dilek Elmaci и Sibel Cevizci во 2015 година, покажаа дека терапиите и активностите со помош на кучиња може да бидат метод на поддршка за рутински процедури за рехабилитација на деца со церебрална парализа и физички и интелектуални пречки.

Во однос на втората група на испитаници, кои се соочуваа со тешкотии во областа на вербални способности и комуникација, резултатите од последната проценка покажаа подобрување на способностите и нивно поместување во гранична линија. Резултатите покажуваат дека и двете терапии - примена на куче и примена на класични вежби беа ефикасни со реализирање и постигнување на одредени цели, но како и во претходната група и тука се забележува зголемена мотивација и волја, односно, при реализирање на вежбите со примена на куче децата не покажаа знаци на умор, за раздика од децата со кои реализиравме класични вежби. Emily Howell-Forbes (2014) во својата студија за влијанието на кучињата во исходот од окупациона терапија кај деца со церебрална парализа, забележала значително повеќе вокализации кај испитаниците кога кучето било присутно. Во корелација со нашите наоди се и резултатите на LaFrance, Garcia \& Labreche во 2007 година, кои покажуваат дека вербалните однесувања на пациентите можат да се подобрат со присуство на тераписко куче. Преку интензивна говорна и јазична терапија во услови на рехабилитација аплицирајќи партиципативно набљудување, истражувачите заклучуваат дека присуството на кучето има потенцијал да го стимулира социјално-вербалното и социјално-невербалното комуницирање.

Кај третата група на испитаници, кои имаа проблеми во однесувањето за време на вршење на секојдневните активности и тешкотии во интеракцијата со врсниците, констатиравме дека присуството на куче овозможува социјална поврзаност дете-куче-врсник, ја подобрува интеракцијата на децата меѓу себе и го подобрува целокупното однесување на испитаниците. Најдобрите и најпозитивните резултати од целото истражување ги добивме во социјалниот домен. Истражувањето на Katy R. Beck, преку анкета за наставници и вработени во основно училиште, посочува дека присуството на кучето може да биде позитивна алатка за мотивација за добро однесување и за завршување на работата кај учениците. Тераписките кучиња им дозволуваат на децата да се чувствуваат сигурни и самоуверени додека ги реализираат дадените задачи. Студијата на Sabrina E.B. Schuck и cop. покажува дека моделот на интервенција со примена на куче 
влијае врз подобрувањето на социјалните вештини на децата и проблематичното однесување и намалувањето на симптомите на АДХД.

\section{Заклучок}

Многу студии посветени на терапијата со примена на животни истакнуваат широк спектар на придобивки за здравјето на дицата вклучени во третманот, но голем дел од истражувањето се карактеризира со мали интервенции во различни области, што резултира со критики за слаб дизајн на студии иди неконзистентна методологија. Ваквите критики се спротивставуваат на силното тврдење меѓ многумина дека интеракцијата со животните има силна и вродена вредност за дицата кои се опфатени. И нашата студија се карактеризира со мал примерок и краток временски период на интервенирање. За целосно интегрирање на терапијата со примена на животни во пракса како прифатен терапевтски модадитет, потребни се поубедливи студии, со цел да се потврдат кдиничките вредности, заедно со разбирање на основниот механизам на човековата реакција на друштвото на животните.

\section{Дитература:}

Alliance OF Therapy Dogs. (2018, July 11) A History of Animal-Assisted Therapy. Retrieved [2020, May] from URL: https://www.therapydogs.com/animal-therapy/

American Veterinary Medica Association. (2019) Animal-assisted interventions: Definitions. Retrieved [2020, May]

from URL: https://www.avma.org/resources-tools/avma-policies/animal-assisted-interventions-definitions

BAUn, M.M., MCCABE, B.W. (2000) The role animals play in enhancing quality of life for the elderly. Academic press.

BECK, K. R. (2015, April 4th) The Impact of Canine-Assisted Therapy and Activities on Children in an Educational setting. Retrieved [2020, May] from Fisher Digital Publications at St. John Fisher College: https://fisherpub.sjfc.edu/cgi/viewcontent.cgi?article=1313\&context=edu cation_ETD_masters

ClonowsKI, J. (2015, September 16) Therapy dogs - The Different types and their benefits. Retrieved [2020, May] from Feinberg consulting, Available from URL: https://feinbergconsulting.com/therapydogs-thedifferent-types-and-their-benefits/

Elmaci, D. T., \& CEvizCI, S. (2015, May 12th) Dog-Assisted Therapies and Activities in Rehabilitation of Children with Cerebral Palsy and Physical and Mental Disabilities. Retrieved [2020, May] from NCBI National Library of Medicine: 
https://www.ncbi.nlm.nih.gov/pmc/articles/PMC4454953/\#B12-ijerph12-05046

FINE AuBrey. (2000) Animal assisted therapy - Theoretical foundations and Guidelines for practices. Academic press.

HARrisOn, P. L., \& OAKLAND, T. (2000-2003) Adaptive Behavior Assessment System. USA: Western Psychological Services.

Howell-Forbes, E., MARXen, K. (2014) Animal-Assisted Therapy: A Dog's Influence on Occupational Therapy Outcomes of a Child with Cerebral Palsy. University of Puget Sound.

Kruger, K. A., \& Serpell, J. A. (2006) Animal assisted interventions in mental health. In Handbook on Animal-Assisted Therapy: Theoretical Foundations. London: Academic Press.

LAFrANCE, C., GARCiA, L., \& LABreChE, J. (2007, May-June 3rd) The effect of a therapy dog on the communication skills of an adult with aphasia. Retrieved [2020, May], from NCBI National Library of Medicine National Institutes of Health:

https://www.ncbi.nlm.nih.gov/pubmed/16950329/

LeVINSON, B., MALLON, G. (1997) Pet-oriented child psychotherapy. Springfield, IL: Charles C. Thomas.

PIllow-PRICE, K., YONTS, N., \& StinSON, L. (2014) Sit, Stay, Read: Improving Literacy Skills Using Dogs. Dimensions of Early Childhood, 42(1), 5-9.

SCHUCK, S., EMmERSON, N., FINE, A., LAKES, K. (2015) Canine-Assisted Therapy for Children With ADHD: Preliminary Findings From The Positive Assertive Cooperative Kids Study. In J Atten Disord. 2015 Feb; 19(2): 125-137.

Tepfer, A., Ross, S., MacDonald, M., Ruell, M. A., RuAux, C., \& BAltzer, W. (2017, April 27th) Family Dog-Assisted Adapted Physical Activity: A Case Study. Retrieved [2020, May] from MDPI:

https://www.mdpi.com/2076-2615/7/5/35/htm\#B45-animals-07-00035 